\title{
STEROLS FROM Setaria italica GRAIN
}

\author{
V. S. Kislichenko, * Z. I. Omel'chenko, \\ and V. V. Vel'ma
}

UDC 635.65:581.19

Foxtail millet (Setaria italica L.) belongs to the family Poaceae (grasses). The plant is widely cultivated in Europe, Asia, Africa, and America. It is included in the Chinese Pharmacopoeia 2000.

Our goal was to identify and determine quantitatively sterols in grain of this plant.

Raw material was extracted exhaustively with $\mathrm{CHCl}_{3}$ in a Soxhlet apparatus. The evaporated extract was methylated by acidified methanol and diazomethane.

The sterol composition was determined by GC-MS, which enabled us to determine accurately the molecular weights of sterols and to differentiate easily compounds with skeletons consisting of 29, 30, or 31 C atoms [1-3].

A total of 12 sterols was identified by analyzing the grain (Table 1).

Table 1 shows that $\gamma$-sitosterol $(2.781 \mathrm{mg} / \mathrm{kg}) ;$ stigmastanol $(1.006 \mathrm{mg} / \mathrm{kg}) ;$ 5-cholesten-3-ol, 24-methyl $(0.913 \mathrm{mg} / \mathrm{kg})$; and campesterol $(0.867 \mathrm{mg} / \mathrm{kg})$ dominated the sterols. According to the literature the sterols from foxtail millet are also present in other plant oils. Thus, campesterol was isolated from rapeseed, soy, and wheat-germ oils. $\gamma$-Sitosterol is one of the main sterols of soy and wheat-germ oils. Stigmasterol occurs also in soy oil. One of the most important sterols is cholesterol or 5 -cholesten- $3 \beta$-ol, which is a precursor in the synthesis of steroidal hormones, bile acids, and vitamin $\mathrm{D}_{3}$. It is involved in cell membrane formation. Cholesterol is a secondary alcohol and can react with higher carboxylic acids or other compounds, even toxic ones (bacterial toxins, snake and spider venom, etc.), detoxifying them and performing protective functions in the organism. It can stick to walls of blood vessels and decrease their elasticity (atherosclerosis) in cases of disrupted cholesterol exchange.

TABLE 1. Sterol Composition of Setaria italica Grain

\begin{tabular}{|c|c|c|c|}
\hline Sterol & $\begin{array}{c}\text { Quantitative content, } \\
\mathrm{mg} / \mathrm{kg}\end{array}$ & Sterol & $\begin{array}{c}\text { Quantitative content, } \\
\mathrm{mg} / \mathrm{kg}\end{array}$ \\
\hline Ergostanol & 0.164 & 5-Cholesten-3-ol, 24-methyl- & 0.913 \\
\hline$\gamma$-Sitosterol & 2.781 & Stigmastanol & 1.006 \\
\hline Stigmasterol & 0.398 & Stigmastan-3,5-diene & 0.376 \\
\hline Cholest-5-en-3-ol, 24-propylidene, $(3 \beta)$ - & 0.390 & Campesterol & 0.867 \\
\hline Lanosterol & 0.185 & Stigmast-4-en-3-one & 0.215 \\
\hline Stigmasta-5,24(28)-dien-3-ol, $(3 \beta, 24 Z)$ - & 0.200 & 9,19-Cyclolanost-24-en-3-ol, acetate, $(3 \beta)$ - & 0.229 \\
\hline
\end{tabular}

\section{REFERENCES}

1. D. W. Brown, A. J. Floyd, and M. Sainsbury, Organic Spectroscopy, J. Wiley, Chichester, New York (1988).

2. V. V. Takhistrov, Practical Mass Spectrometry of Organic Compounds [in Russian], Izd. LGU, Leningrad (1977).

3. Y. Narumi and S. Takatsuto, Biosci. Biotech. Biochem., 63, 10 (1999).

National Pharmaceutical University, 61002, Ukraine, Kharkov, ul. Pushkinskaya, 53, fax: (+380572) 67 93 63, e-mail: cnc@ukrfa.kharkov,ua. Translated from Khimiya Prirodnykh Soedinenii, No. 2, p. 241, March-April, 2009. Original article submitted October 30, 2008. 